\title{
Ganglioneuromatous Polyposis of the Colon: a Case Report and a Review of the Literature
}

\author{
Cristina D’Ercole, Angelo Zullo, Maria Consiglia Bragazzi, Cesare Hassan, Roberto Lorenzetti, \\ Salvatore Maria Antonio Campo \\ Gastroenterology Unit, Ospedale Nuovo Regina Margherita, Rome, Italy
}

\begin{abstract}
This report discusses a case of ganglioneuromatous polyposis of the colon in a woman without any other systemic manifestations. To our knowledge, this is the first report of the few cases of intestinal ganglioneuromatosis described in the literature presenting with abdominal pain and bloody diarrhea as unique clinical signs, with multiple polyps confined in the right side of the transverse colon and in the ascending colon. Of note, the endoscopic feature of such a rare entity - which involves the enteric nervous system - may mimic that of sessile adenomatous polyps which are diagnosed at routine colonoscopy. We emphasized that this condition may be misdiagnosed, and we reviewed the reported cases in the literature. (J Dig Endosc 2011;2(1):18-21)
\end{abstract}

Key words: Colonic polyps - Ganglioneuromatous polyposis - Enteric nervous system

\section{Introduction}

Intestinal ganglioneuromatosis is a benign proliferation of nerve ganglion cells, nerve fibers, and supporting cells of the enteric nervous system that can result in abnormally large enteric neuronal cells in the myenteric plexus, which can be associated with the von Recklinghausen's disease and other multiple tumor syndromes. [1,2] We report a case of a woman diagnosed with colonic ganglioneuromatous polyposis of the colon following surgery. We reviewed the literature and discussed the endoscopic pitfall of this rare condition.

\section{Case report}

A 64-year-old woman was referred to our Unit because a 2-year history of recurrent episodes of abdominal pain with mild bloody diarrhoea and mucus in the stool. Bariumcontrast study demonstrated the presence of multiple filling defects in the ascending colon (Figure 1). The patient had no family history for intestinal diseases or neoplasia.
Examination revealed tenderness in the lower abdomen, with normal bowel sounds, and no detectable masses. Rectal examination showed the presence of haemorrhoids. Colonoscopy revealed diverticulae in the sigmoid and descending colon and presence of flat, multiple, agglomerated, sessile polyps, $2-4 \mathrm{~mm}$ in size, located in the right side of the transverse colon and in the ascending colon (Figure 2). The histology of a resected polyp was adenomatous polyp with low grade dysplasia. Because of the extensive nature of polyposis, the patient underwent right hemicolectomy to rule out an attenuated form of familial adenomatous polyposis. Unexpectedly, the post-surgical

\footnotetext{
Reprints requests and correspondence:

Salvatore Maria Antonio Campo, M.D.

Gastroenterology Unit

Ospedale Nuovo Regina Margherita, Rome, Italy

Phone: +390658446608; Fax. +390658446533

E-Mail: salvatorecampo@yahoo.com
}

Received: 8th Sept $2010 \quad$ Accepted: 19th Dec 2010 


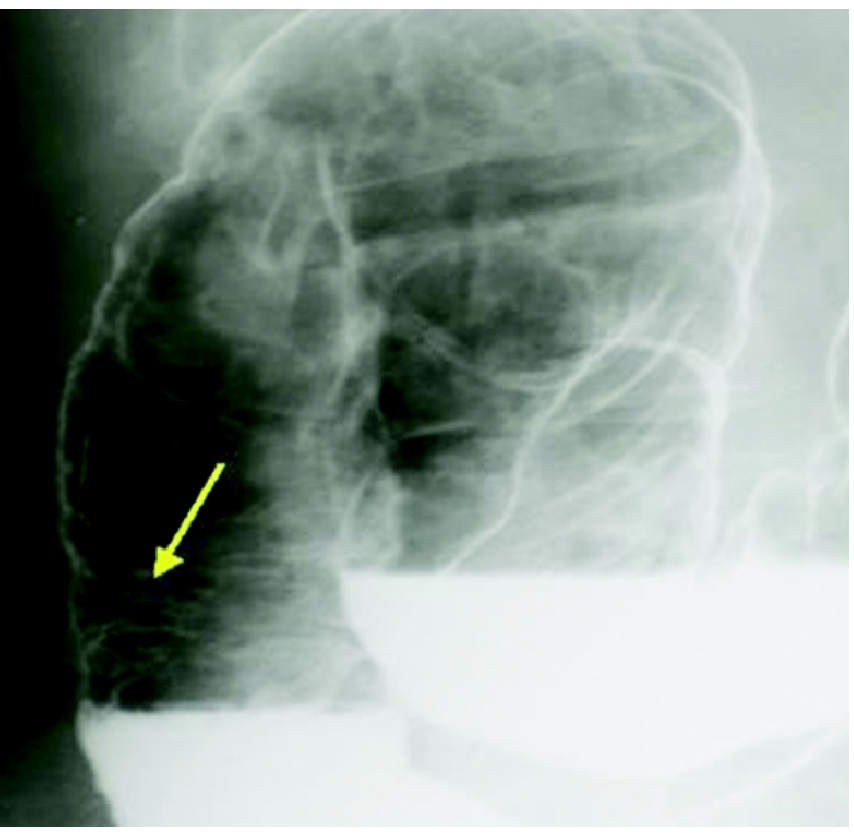

Figure 1: Figure 1: Barium-contrast study showing small filling defects in the ascending colon (arrow).

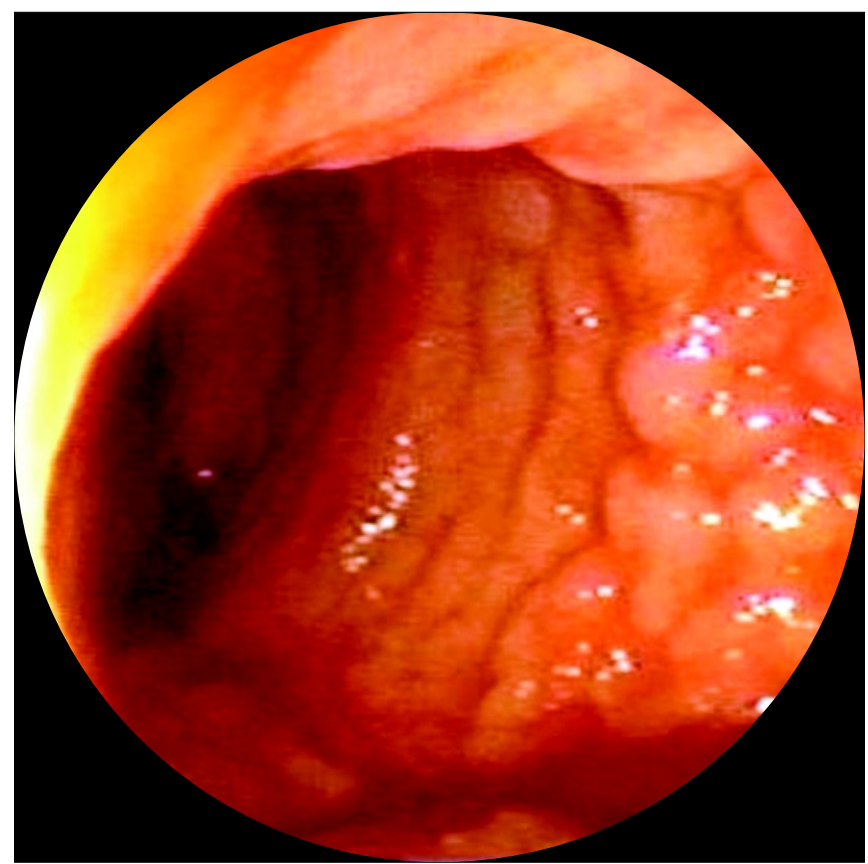

Figure 2: Endoscopic feature of several polyps in the ascending colon.

histological examination showed polyps with normal mucosa, whereas aggregates of neurologic fibers, Schwann cells and rare ganglial cells were present in the submucosa. Immunohistochemical studies using antibodies to S-100 protein, neuronspecific enolase (NSE) and neurofilament protein (NFP) were positive. Therefore, the final diagnosis was ganglioneuromatous polyposis of the colon (Figure 3). A total body CT-scanning did not demonstrate any other

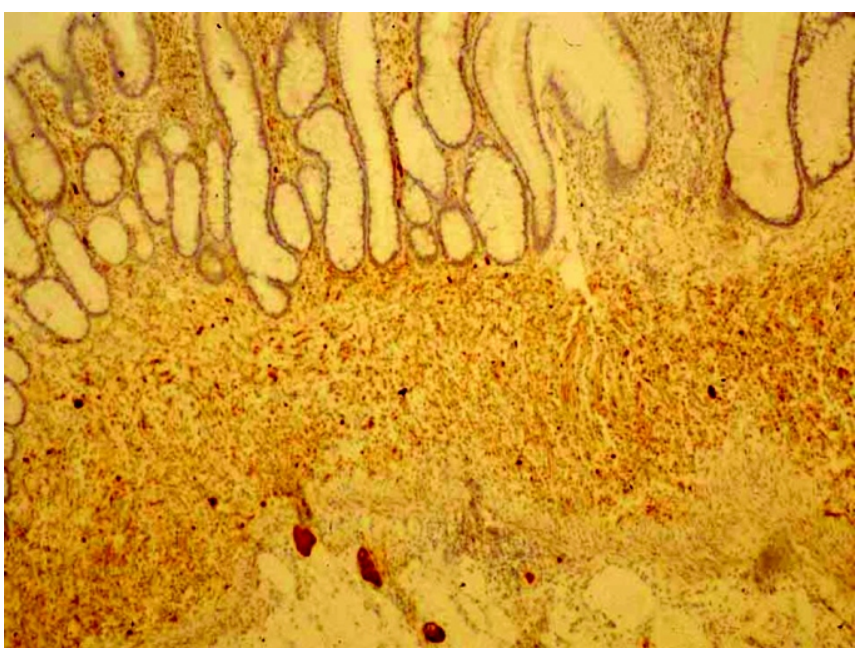

Figure 3: Neuron-specific enolase stain showed the neural nature of the polyps.

abnormality. Following colonic resection, diarrhea resolved. No other polyps in the residual colon were found at 3-year endoscopic follow-up.

\section{Discussion}

Intestinal gganglioneuromatosis has been essentially described in children and rarely in adults, generally associated with juvenile polyps or multiple adenomatous polyps. It is characterized by the presence of benign, hamartomatous polyps with an overgrowth of nerve ganglion cells, nerve fibers, and supporting cells in the gastrointestinal tract.[2,4] At endoscopy, the finger-like polyps more likely suggest ganglioneuromatosis, while the raspberry-like polyps correspond to adenomas.[3] Depending on the great variability in neural, supportive, and ganglion cell content and demarcation, three forms have been recognized: 1) polypoid ganglioneuroma, never associated with von Recklinghausen's disease or endocrine multiple neoplasia, with a typical juvenile polyp-like pattern or neurofibromatous pattern; 2) diffuse ganglioneuromatosis, associated with systemic disorders, such as MEN IIb, Cowden syndrome, and Ruvalcaba-Myhre-Smith syndrome; and 3) ganglio-neuromatous polyposis. Despite the latter form of intestinal ganglioneuromatosis is quite rare, it may be associated with adenomatous polyps or juvenile polyposis, but not coexists with neoplasia type IIb, neurofibromatous type I, and Cowden syndrome.[5-15] A familial form of such a disease has been once reported.[16] Two morphologic patterns have been described: 1) transmural type, characterized by neural hyperplasia in all layers of the bowel wall with predominant involvement of the myenteric plexus, often associated with multiple endocrine neoplasia IIb, and 2) mucosal type with predominant involvement of the mucosa without concomitant hyperplasia of the myenteric plexus, associated 
Table 1: Main data of case reports of intestinal ganglioneuromatosis in the literature

\begin{tabular}{|c|c|c|c|c|c|c|c|}
\hline Ref. & $\begin{array}{l}\text { No. of } \\
\text { Patients }\end{array}$ & Age & Sex & Symptoms & Clinical features & $\begin{array}{l}\text { Endoscopic } \\
\text { finding }\end{array}$ & $\begin{array}{l}\text { Histological } \\
\text { diagnosis }\end{array}$ \\
\hline \multirow[t]{3}{*}{1} & 28 & 48 & $14 / 14$ & $\begin{array}{l}\text { Rectal bleeding } \\
\text { Weight loss } \\
\text { Abdominal pain }\end{array}$ & Intestinal tumour (2) & NA & $\begin{array}{l}\text { Polypoid } \\
\text { ganglioneroma }\end{array}$ \\
\hline & 7 & 39 & $5 / 2$ & $\begin{array}{l}\text { Abdominal pain } \\
\text { Rectal bleeding }\end{array}$ & $\begin{array}{l}\text { Multiple cutaneous(3) } \\
\text { Elephantiasis (1) }\end{array}$ & & Polyposis GNM \\
\hline & 8 & 35 & $7 / 1$ & $\begin{array}{l}\text { Rectal bleeding } \\
\text { Megacolon } \\
\text { Abdominal pain }\end{array}$ & & & Diffuse GNM \\
\hline 2 & 2 & 45 & $2 / 0$ & Unknown & None & Polyps & Diffuse GNM \\
\hline 3 & 10 & 55 & $6 / 4$ & $\begin{array}{l}\text { Abdominal pain } \\
\text { Diarrhea } \\
\text { Obstruction }\end{array}$ & $\begin{array}{l}\text { MEN Ilb(1) } \\
\text { vRN (2) } \\
\text { Adenomatous polyp (1) } \\
\text { Cowden disease (1) }\end{array}$ & $\begin{array}{l}\text { Megarectum(1) } \\
\text { finger-like polyp (2) } \\
\text { Rasberry like polyp (2) }\end{array}$ & $\begin{array}{l}\text { Diffuse GNM (4) } \\
\text { Appendicular GNM } \\
\text { Rectal GNM (1) } \\
\text { Sigmoid GNM (2) } \\
\text { Polyposis GNM (1) }\end{array}$ \\
\hline 4 & 1 & 41 & $1 / 0$ & Rectal bleeding & Cutaneous lypomas & $\begin{array}{l}100 \text { sessile polyps } \\
1-2 \text { mm colon, } \\
3 \text { sessile polyps in stomach }\end{array}$ & Polyp GNM \\
\hline 9 & 1 & 68 & $1 / 0$ & Unknown & unknown & Polyp & Polyp GNM \\
\hline 10 & 1 & 77 & $0 / 1$ & & $\begin{array}{l}\text { Adenocarcinoma } \\
\text { Hyperparathyroidism }\end{array}$ & Polyposis & Polyposis GNM \\
\hline 11 & 1 & 40 & $1 / 0$ & Unknown & Adenocarcinoma & Polyposis & Polyposis GNM \\
\hline 12 & 3 & 67 & $2 / 1$ & Diarrhea & None & $\begin{array}{l}\text { Polyposis cecum } \\
\text { and right colon }\end{array}$ & Diffuse GNM \\
\hline 13 & 1 & 32 & $1 / 0$ & Unknown & NF type I & Unknown & Diffuse GNM \\
\hline 14 & 1 & $0 / 1$ & None & None & Sessile polyp & Polyp GNM & \\
\hline 15 & 1 & 5 & $0 / 1$ & Intussusception & Unknown & Polyp & Polyp GNM \\
\hline 16 & 1 & 38 & $1 / 0$ & Unknown & Unknown & Juvenile polyposis & Polyposis GNM \\
\hline 17 & 5 & & & Unknown & $\begin{array}{l}3 \text { MEN 2b, } 1 \text { WRN } \\
1 \text { adenocarcinoma } \\
1 \text { adenomatosis polyposis }\end{array}$ & & \\
\hline 18 & 1 & & & Diarrhoea & $\begin{array}{l}\text { Intrathoracic noduclear } \\
\text { stroma }\end{array}$ & Normal & Diffuse GNM \\
\hline
\end{tabular}

vRN = von Recklinghausen neurofibromatosis; GNM = ganglioneuromatosis; NF = Neurofibromatosis

with von Recklinghausen's disease, adenocarcinoma of the colon, and multiple adenomas.[17] Differently from our report, in most cases polyps were found in the entire colon. Rectal bleeding, abdominal pain, watery diarrhoea of several months duration have been observed in these patients. [18]

The pathogenesis remains unclear, representing an unusual hyperplasia of the nerve plexus related to circulating nerve growth factors and /or selective expression of the mutated neurofibromatosis gene within subpopulation of autonomic neurons. The pathophysiology is related to a complex hyperplasia of several peptidergic, cholinergic, and probably adrenergic nerve fibres. [4,17]
Diagnosis of intestinal ganglioneuromatosis has to be exclusively established on the basis of the microscopic examination by diffuse Schwann cell hyperplasia expressing S100 protein in close contact to nerve fibers expressing neurofilament, tau protein, synaptophysin, and to ganglion cells (Table 1). Symptoms including rectal bleeding, watery diarrhoea, abdominal pain and, seldom, acute occlusion have been reported. The endoscopic feature comprises presence of multiple finger-like polyps localized in colon. The von Recklinghausen's disease, multiple endocrine neoplasia type IIb or Cowden's disease, a nonfamilial adenomatous polyposis or colonic adenocarcinoma can be associated disorders. $[1,6,8,10,17,18]$ 
To our knowledge, this is the first report of a transmural type ganglioneuromatous polyposis presenting with abdominal pain and bloody diarrhea, associated with multiple adenomatous polyps which are confined in the ascending and transverse colon, without any evidence of other neuroendocrine or inherited associated diseases. The coexistence of ganglioneuromatous polyposis and adenomatous polyps into the colon remains unclear. However, after colonic surgery no other polyps were found in the residual colon. At 3-year follow-up neither polyp recurred nor the patient developed features suggestive of multiple endocrine neoplasia or other diseases.

\section{Conclusion}

Ganglioneuromatous polyposis of the colon is a rare condition characterized by the presence of 20-40 sessile or pedunculated polyps, which may be detected in the colon. This rare condition may be associated with adenomatous polyps or juvenile polyposis or multiple endocrine neoplasia. Its pathogenesis remains unclear, although an unusual hyperplasia of the nerve plexus due to circulating nerve growth factors and/or selective expression of the mutated neurofibromatosis gene within subpopulation of autonomic neurons have been showed. Gastroenterologists have to be aware of the higher risk of occlusion and intestinal neoplasia associated with this rare condition which should be also kept in mind when multiple, adjacent polyps are detected at colonoscopy.

\section{References}

1. Kris M Shekitka, Leslie H Sobin: Ganglioneuromas of the gastrointestinal tract: relation to von Recklinghausen's disease and other multiple tumor syndrome. Am J Surg Pathol 1994;18:250-7.

2. Weidner N, Flanders DJ, Mitros FA. Mucosal ganglioneuromatosis associated with multiple colonic polyps. Am J Surg Pathol 1984;8:779-86.

3. Chambonnière ML, Porcheron J, Scoazec JY, Audigier JC, Mosnier JF. Intestinal ganglioneuromatosis diagnosed in adult patients. Gastroenterol Clin Biol 2003;27:219-24.

4. Chan OT, Haghighi P. Hamartomatous polyps of the colon: ganglioneuromatous, stromal, and lipomatous. Arch Pathol Lab Med 2006;130:1561-6.
5. Di Liberti JH, Weleber RG, Budden S. Ruvalcaba-MyhreSmith syndrome: a case with probable autosomal-dominant inheritance and additional manifestations. Am J Med Genet 1983;15:491-5.

6. Lashner BA, Riddell RH, Winans CS. Ganglioneuromatosis of the colon and extensive glycogenic acanthosis in Cowden's disease. Dig Dis Sci 1986;31:213-6.

7. Suzuki T, Kikuchi K, Tomioka H, Tanifuji K. A case of colonic polypoip ganglioneuromatosis - a light microscopy, electron microscopy and immunohistochemical study. Gan No Rinsho 1988;34:365-73.

8. Smith VV, Eng C, Milla PJ. Intestinal ganglioneuromatosis and multiple endocrine neoplasia type $2 \mathrm{~B}$ : implications for treatment. Gut 1999;45:143-6.

9. Artaza T, Garcia JF, Gonzalez C, Amengual M, Mazarro A, Rodríguez R, Sánchez JJ. Simultaneous involvement of the jejunum and the colon by type- 1 neurofibromatosis. Scand J Gastroenterol 1999;34:331-4.

10. Macenlle R, Fernández-Seara J, Pato M, Pereira J, Pascual P, Montero M, Miranda C. Ganglioneuromatous polyposis of the colon associated with adenocarcinoma and primary hyperparathyroidism. Eur J Gastroenterol Hepatol 1999;11: 447-50.

11. Kanter AS, Hyman NH, Li SC. Ganglioneuromatous polyposis: a premalignant condition. Report of a case and review of the literature. Dis Colon Rectum 2001;44:591-3.

12. Michalak S, Croué A, Valo I, Dib N, Boyer J. Diffuse colonic ganglioneuromatous polyposis. Ann Pathol 2004;24:129-34.

13. Thway K, Fisher C. Diffuse ganglioneuromatosis in small intestine associated with neurofibromatosis type 1. Ann Diagn Pathol 2009;13:50-4.

14. Mendez IM, Pereda T, Rodriguez FJ, Funez R, Sanchez A. Solitary colonic polypoid ganglioneuroma. Diagn Pathol 2008;3:20.

15. Soccorso G, Puls F, Richards C, Pringle H, Nour S. A ganglioneuroma of the sigmoid colon presenting as leading point of intussusception in a child: a case report.J Pediatr Surg 2009;44:17-20.

16. Mendelsohn G, Diamond MP. Familial ganglioneuromatous polyposis of the large bowel. Report of a family with associated juvenile polyposis. Am J Surg Pathol 1984;8:515-20.

17. d'Amore ES, Manivel JC, Pettinato G, Niehans GA, Snover DC. Intestinal ganglioneuromatosis: mucosal and transmural types. A clinicopathologic and immunohistochemical study of six cases. Human Pathol 1991;22:276-86.

18. Behrendt N, Anderson J, Rossen K. Intestinal ganglioneuromatosis - a rare cause of chronic diarrhea. Ugeskr Laeger 1998;160:7139-40.

Source of support: Nil; Conflict of interest: none declared 